(23)

\title{
荷重線リアルタイム表示システムの開発と 下腿義足アライメント調整への応用
}

(労災リ八工学センター) 森 本 正 治, 山 下 保

\section{1.はじめに}

下肢切断者の活動度を向上させるために最近の義 足には種久の高度な立脚制御機能や遊脚制御機能が 組み込まれる傾向にある。これらの機能が適切に作 動するためには, 切断者と義足の力学的な接合部で あるソケットの適合と並んで, 義足の主要構造部品 間の空間的な相対位置関係であるアライメントを適 切に調整しておくことが先ず必要となる.

我々は義足の機能やアライメントの状態を, 義足 や人体に取り付けたセンサ群によって工学的に計 測・評価し，義肢装具士が最適状態に調整していく 手順を明らかにして, それらの調整過程を工学的に 再構築することをめざして研究を進めてきた ${ }^{1,2)}$. その過程から, 義足に作用する力学量(力とモーメ ント)をリアルタイムで表示することによりアライ メント調整過程に有益な情報を義肢装具士へ即座に フィードバックすることができると推測されたの で，これを実現するシステムを試作し，主として静 的アライメントや動的アライメントの調整過程, 押 よび滕継手の立脚制御機能の計測評価に用いてき た。

第 2 章では従来の義足アライメント調整過程を考 察し, 義足に作用する荷重線をリアルタイムで表示 することにより，アライメント調整過程に有益な情 報を義肢装具士へ即座に伝えることができると推測 した経緯について述べる. 第 3 章では, 試作したシ ステムのハードゥェアとソフトウェアについて述べ る.第 4 章では，これを義足の静的アライメントと
動的アライメントの調整過程に応用した結果につい て述べる. 第 5 節では, 義足の膝継手の立脚制御機 能の 1 つである荷重ブレーキの計測評価に応用した 結果について述べる。

\section{2. 義足アライメント調整手順のエ学的 検討}

義肢装具士が長年の経験の蓄積により獲得したノ ウハウに基づいて行う義足アライメント調整につい て, 最も基本的な下腿義足のアライメント調整過程 を, ベンチアライメント, 静的アライメント, 動的 アライメントの各段階に分けて工学的に検討した。

\section{1 ベンチアライメント}

義足部品相互間の標準的な位置関係を体重をかけ ない無負荷状態で設定するアライメントで, 各義足 部品ごとに異なり，メーカによる所定の方法が明記 されている。矢状面のベンチアライメントは「滕蓋 勒帯中央を通る水平線でソケットを二等分した点 (溙蓋勒帯のほぼ心)を通る鉛直線が，足部の踵と BALLの二等分点を通るようにソケットと足部の 位置関係を組み立てる.」とあるが3), 最近の弾性変 形量の大きい足部・足継手部では, 踵寄りを通るよ うに設定している。その量は切断者の体重や活動度 によって異なると考えられるが，製品の取扱い説明 書には定量的な記述はない. 静的アライメントとの 関連で，体重や活動度を考慮した補正を行えるデー 夕が各製品に添付されていなければならないが，そ の基礎となるデー夕の収集には義足に 6 分力計を組 み込み, 関節角度計を取り付けて荷重線を表示させ 
るシステムが役立つと考えられる。

\section{2 静的アライメント}

体重をかけた静止または準静的な状態で立位の安 定性を主体にして義足構成部品の相互位置関係を決 める静的アライメントは，重鍾やバランス治具など を用いて行われている。

「義足を装着し，両足の踵の開き幅を 5 〜 $10[\mathrm{~cm}]$ として，両脚に均等に体重をかける。足部の回旋角 度は健側と同じ角度にする。断端がソケットに適切 に装着された状態で骨盤が水平になるように，義足 長を決定する.」とあるが3)，両脚に均等に体重をか けているかどうかのチェックは定量的に行われてい ない. 下腿パイロン部に 6 分力計（直交 3 軸方向の カとモーメントが計測できる荷重センサ）を組み込 むことにより，義足側の体重負荷が定量的にわか る。さらに直立位で，荷重線が足底のどこを通る か，膝軸水平面のどこを通るかがわかり，足部・膝 部・ソケット間の相対位置関係の異常が確実に検出 できて，修正のための具体的な情報が得られる。そ の結果, 安定直立位の調整を正確かつ確実に行える ようになると考えられる。

この段階で，アライメントの異常により足底が均 等に接地せず内外反，底背屈方向に偏りが発生する 場合がある．従来はこれをりケットと断端の隙間の 遍在，足の内外方向，前後方向の着地位置などを観 察して修正していたが，前述のように義足に対する 荷重線の位置と大きさを表示することができれば， より正確かつ簡便に最適な調節が可能になると考え られる。

\section{3 動的アライメント}

歩行運動の相の移行が滑らかに行われるように義 足構成部品の調整を行い, 汃, 部品相互の位置関 係を決める動的アライメントの調整作業は，義肢装 具士が経験を積み重ねて得たノウハウに依存して行 われる。

切断者が歩行に慣れた段階で歩容を観察し，以下 の項目に注意して正常肢の歩容に近づけるように， ソケットに対する相対位置関係の微妙な調整，継手
部のコンプライアンスの調整, 制御機構の調整が行 われる。

1）接踵時に㬵が $5-10$ [度] 屈曲位を保つ

2）足部の滑らかなロールオーバー

3）足底が床面に片当りせずに接地する

4）つま先離れ時に膝がわずかに屈曲位を保つ

5）遊脚期の断端とソケットの緩みが少ない

これらについて，切断者の歩容の前方と後方から の観察で内外側方向のアライメント調整を行い, 側 方からの観察で前後方向のアライメント調整を行っ ている.

義足下腿部に 6 分力計を組み込むことで，足底の ZMP 軌跡の経時変化を知ることができ，足部の口 ールオーバーの滑らかさや足底と床面の片当りの程 度を検知することができる。また，㯟部にフレキシ ブル関節角度計を装着することで，接踵時と離床時 の膝屈曲角度を計測でき，膝の屈曲・伸展の程度を 定量的に知ることができる。

立脚中期の膝の不安定性により膝軸が摇動するよ うな場合には，膝軸に装着した角度計により検出す ることができる。また，角度変化として現れにくい 小さい摇動の場合には，膝軸水平面を通る荷重線の 摇動として 6 分力計の出力から検出できる.

以上の検討から, 義足下腿部に 6 分力計を組み込 み，両下肢の関節に角度計を装着し，足底スイッチ を靴底に着ければ，義足側と健足側との体重負荷の 比率, 立脚期間の比率, 足底 $Z \mathrm{MP}$ 軌跡の時間変 化, 膝継手軸まわりの屈曲・伸展モーメントの時間 変化, 足継手部の動的な底背屈, 内外反のコンプラ イアンスなどを知ることができ，動的アライメント の微妙な調整段階で，運動学的な知見として現れに くい義足の力学的な諸元を明らかにできると考えら れる。

その結果，従来は言葉や図で表現して説明するこ とが極めて困難であったプロセスを定量的に記述す ることができるようになり，義肢装具士の間の技術 の伝達を円滑に進めることも可能になると期待され る。 


\section{3. 荷重線リアルタイム表示システムの 開発}

義足に作用する力とモーメントを可視化表示でき れば，義足アライメントの調整を明確な根拠に基づ いて行うことが可能になり, 前節で述べた多くの場 面で利用できると考えられる。これを奏現するため に，パイロン・スタディ計測手法を応用して，下腿 パイロン部に組み込んだ 6 分力計を主体とし, 導電 性ゴム方式フレキシブル関節角度計を補助とする計 測システムを構成し，計測データから義足に作用す る荷重線に沿った力ベクトルとモーメントベクトル をリアルタイムで計算処理して表示するようにし た。

\section{1 荷 重 線}

物体に作用する複数の力とモーメントは，剛体の 力学によれば, 互いに平行な単一の力とモーメント に合成できる。6 分力計を組み込んだ義足下腿部セ グメントを剛体とみなせば, 6 分力計の出力から得 られる足継手部および膝継手部の反力と反モーメン トから，互いに向きが平行な単一の力ベクトルと単 一のモーメントベクトル（トルクベクトル）を求め ることができる。この方向を荷重線 (Screw Line) と定義する。6 分力計は義足に組み込まれるため, 求められる力とモーメント（トルク）は義足に固定 した移動座標系に基づく。床反力計と空間座標計測 装置で構成される一般的な運動計測システムで荷重 線を求める場合に較べて，義足と荷重線の相対位置 関係を容易に求めることができ，誤差要因も少な い.

\section{2 ハードウェア}

システムの全体構成を図 1 に示す。義足下腿部に 組み込んだ 6 分力計 (PLC：Pylon Load Cell) の出 力と, 足継手角度, 膝継手角度の信号を $\mathrm{A} / \mathrm{D}$ 変換 器からパソコンに取り込み, 義足に作用する荷重線 をリアルタイムで表示する。

義足下腿部にはパイロン型 6 分力計 ${ }^{1)}$ を組み込 む。義足側の足継手部, 膝継手部には, 導電性ゴム

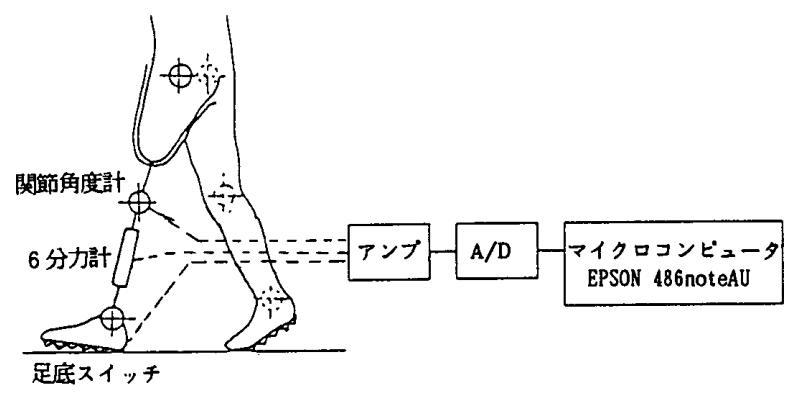

図 1 リアルタイム荷重線計測・表示システム

方式のフレキシブル関節角度計を取付けて, 歩行中 の義足継手部の角度情報をリアルタイムで表示させ ることも可能である. 本角度計 ${ }^{4)}$ は, 過度の屈曲変 形に対しても破損せず，臨床に必要な精度を十分に 満足した 2 軸の角度情報を得ることができる. 装着 には, 予め前加工済みの高密度発泡ウレタンとシリ コンゴムシートを, 個々の取付形状に合わせて加工 し，弾性シアノアクリレート系接着剤で固定するよ うにして，装着の手間を省いた。

データ収録には,ノート型パソコン（PC 486 noteAU）を用いた. センサとの間は $15[\mathrm{~m}]$ の極細 多芯シールド線を用いて軽量化をはかった.システ ム全体は $10[\mathrm{~kg}]$ 以内で小型のスーツケースに納め ることができ，可搬性を高めることができた。

\section{3 ソフトウェア}

データ収録。荷重線計算・画面表示を行うプログ ラムを，漢字表示が可能で周辺ライブラリが豊富な MS-FORTRAN を用いて開発した。

プログラムのフローを図 2 に示す。用いる 6 分力 計と角度計の特性值データおよび被験者の義足に組 み込んだ位置デー夕を最初に読み込んでおき，A/ $\mathrm{D}$ 変換器を介して 1 組づつデー夕を取り込んで物理 単位系に変換し, 足底と膝継手に作用する 6 分力を 計算する。この值に基づいて義足に作用する荷重線 (Screw Line) の座標を計算し, 矢状面と前額面と に投影表示した図をパソコンのグラフィック画面上 に表示する。これを連続して同期あるいは非同期で 行わせながら，キーボードから割り込みをかけて画 面表示を凍結したり，画面のハードコピーをプリン タへ出力したりすることが可能である。同期時のサ 


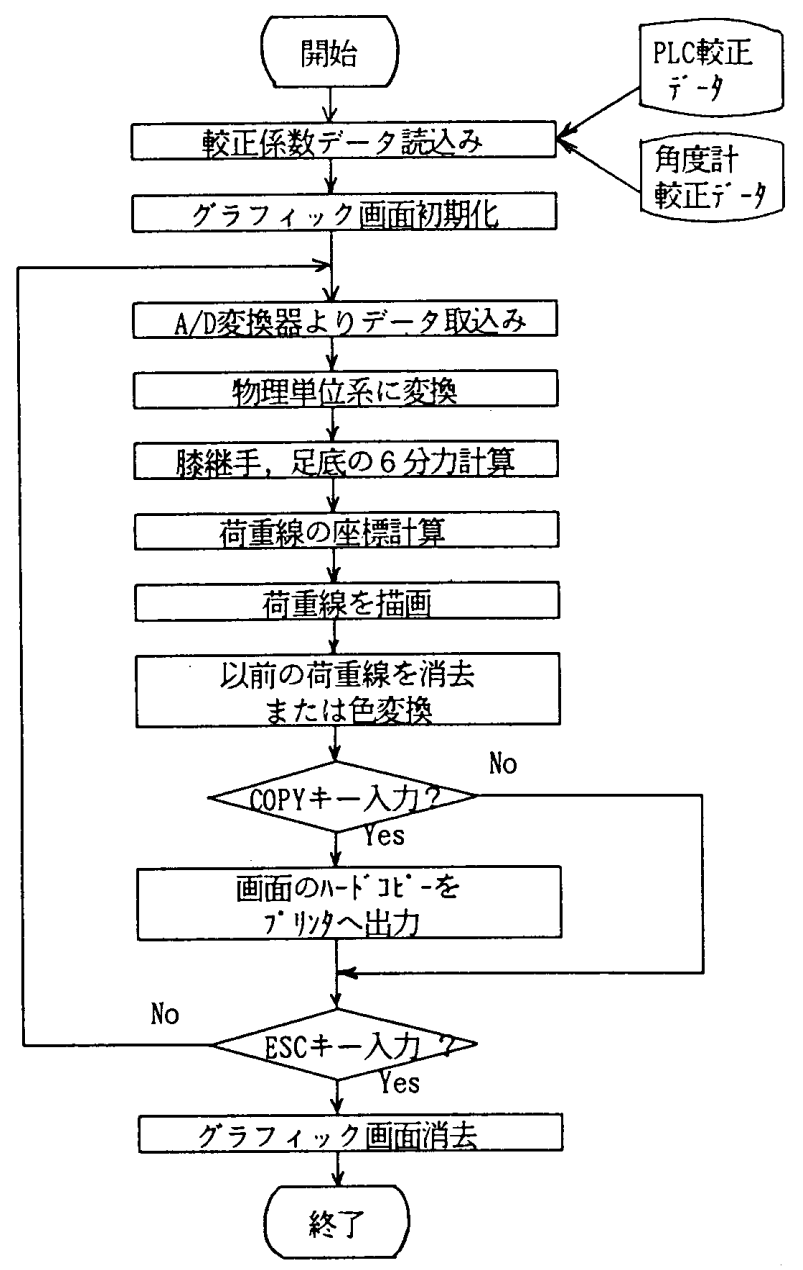

図 2 訫測・表示プログラムのフローチャート

ンプリング周波数はパソコンの演算処理速度に依存 し, 本システムでは最大 $50[\mathrm{~Hz}]$ である。義足と荷 重線の位置関係が分かりやすいように, 足部, 足継 手中心位置, ソケット, 膝中心位置などを図中に重 ね表示できるようにした。また，別のプログラムに より一旦記録された計測データを読み出して, CRT 画面上に速度を変えて再生表示が行えるよう にした。

\section{4. アライメント調整過程への応用}

\section{1 直立位の荷重線におよぼすアライメント の影響}

直立位で義足側に体重の約 $1 / 2$ をかけた静止直立 位での，義足に作用する荷重線をリアルタイム表示 し，その一瞬のデータを画面のハードコピーとして プリンタに出力した。 中立位 (Neutral) を基準にし
て，ソケットに対して足部を内外側に $15[\mathrm{~mm}]$ 並 行移動した場合を図 3 に, 前後に移動させた場合を 図 4 に示す。

足部を内 (外) 側に並行移動すると，外(内)側へ倒

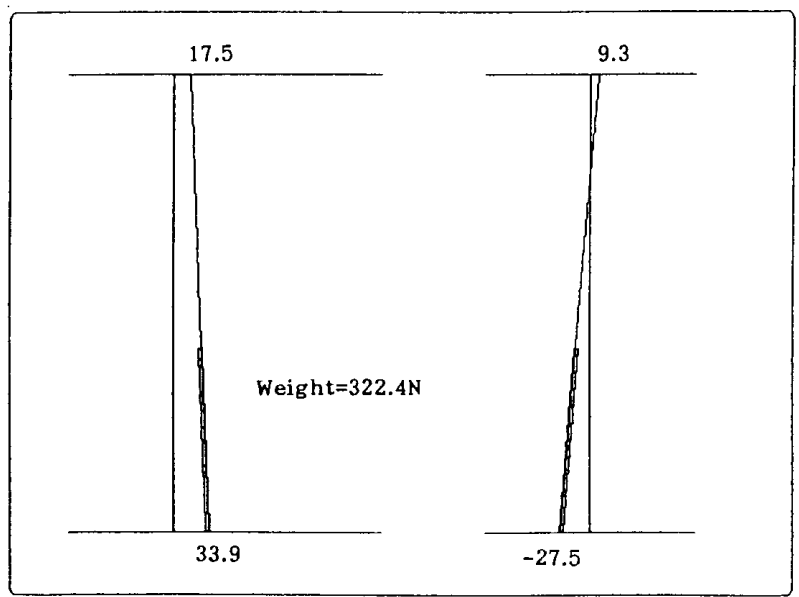

(a) 足部内側移動 $15 \mathrm{~mm}$

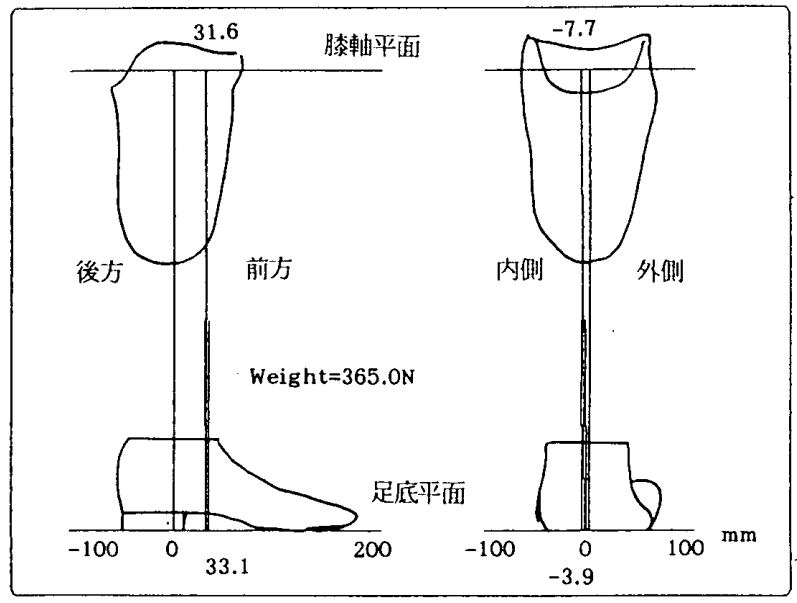

(b) 中立位

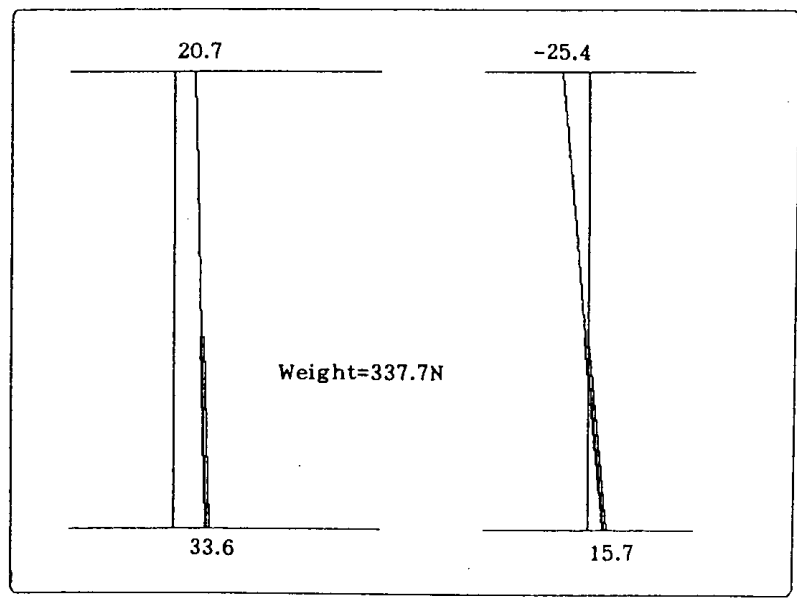

（c）足部外側移動 $15 \mathrm{~mm}$

図 3 直立位の荷重線におよぼすアライメントの影響一 足部の内外側平行移動 


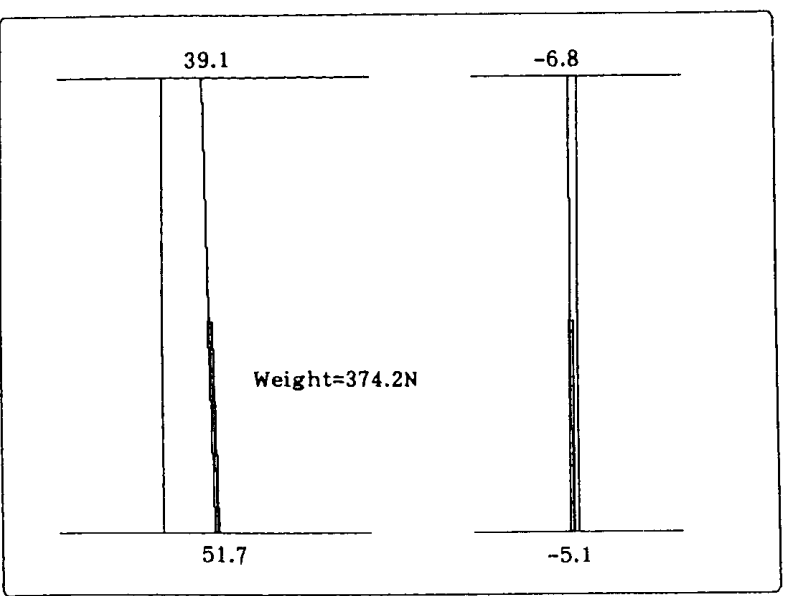

(a) 足部後方移動 $15 \mathrm{~mm}$

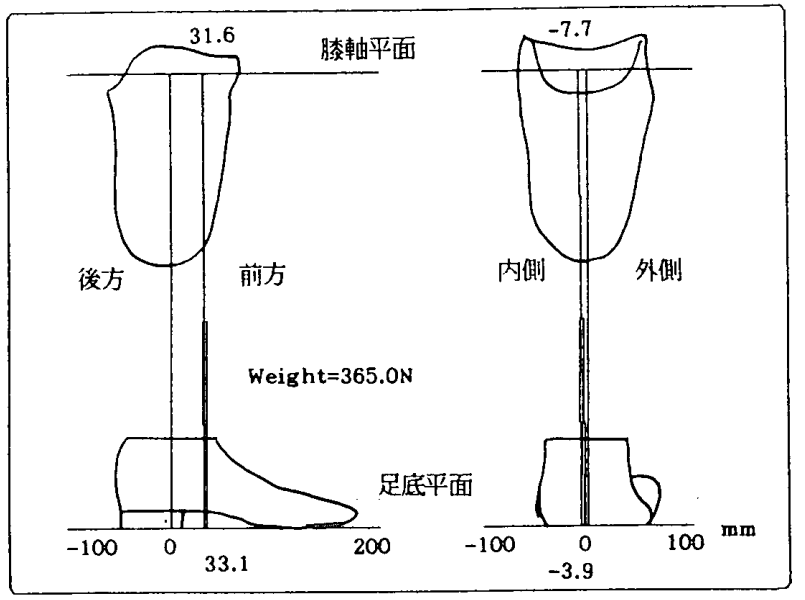

(b) 中立位

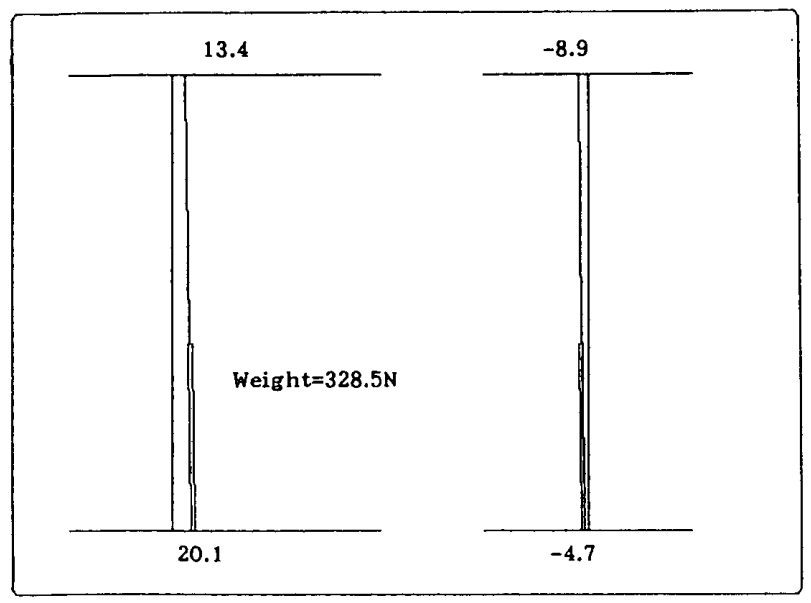

(c) 足部前方移動 $15 \mathrm{~mm}$

图 4 直立位の荷重線におよぼすアライメントの影響一 足部の前後方向平行移動

れ易くなり，これを防ぐために被験者は義足を外側 へ開いて（内側へ寄せて）立位姿勢をとる。このた め, 荷重線は足部の内(外)側を通る。

足部を前 (後) 方へ並行移動すると, 直立時に義足
足部が健足側より前(後)に位置し, 荷重線が義足足 部の後(前) 方寄りを通り, 後(前) 方への倒れに対す る抵抗が小さくなる.

これらは，いずれも直立位での一瞬の荷重線を示 すが，直立位を保持した状態では荷重線に微少な動 摇がみられる。荷重線が足底平面および膝軸平面と 交叉する位置の軌跡の動摇巾は，従来用いられてい るZMP 軌跡の動摇门と類似の評価指標として用い ることができると考えられる。

\section{2 アライメント調整の各過程における 荷重線}

下腿切断の被験者 1 名 (20 歳代の活動的な男子) について，4名の熟練義肢装具士によるアライメン 卜調整過程の各段階における荷重線を計測した。各 義肢装具士による最終アライメントには違いがある ものの，一定の範囲内に収まる傾向が見られた。

義肢装具士 T.N.による下腿義足装着者のアライ メント調整過程の各段階に抢ける荷重線の例を, 立 位について図 5.1 に, 平坦路歩行について図 5.2 に 示す。

図 5.1 は立位保持動作の約 20 秒間の荷重線の変 動を重ねて表示したもので，（a）静的アライメント 調整終了時に較べて (b) 動的アライメント調整終了 時(静的アライメントの後,さらにソケットを約 5 [度]外転させ，足部を約 $3[$ 度]内旋させた）の方が, 荷重線が膝軸および足継手軸の前方寄りを通るよう になるとともに，トルクが殆ど作用しなくなる。

図 5.2 は平坦路歩行時の荷重線の変化を表示した ものである。動的アライメント調整終了時には，卜 ルクが小さくなり，蹴りだし時に見られた大きなピ ークが無くなり義足に無理な回旋力が作用しなくな っている。接踵時と離床時に荷重線に沿った力べク トルの足底に平行な成分が, それぞれ進行方向と後 退方向になっており, 通常の床反力ベクトルの水平 成分に較べて逆方向になっているが，これは本シス テムの座標系が義足に固定した移動座標系になって いるためであり，義足の空間運動を考慮すれば床反 カベクトルと等価になる。義足の継手部と荷重線と の相対位置関係を知るには, 義足に固定した移動座 標系の方が便利であると考えられる。 


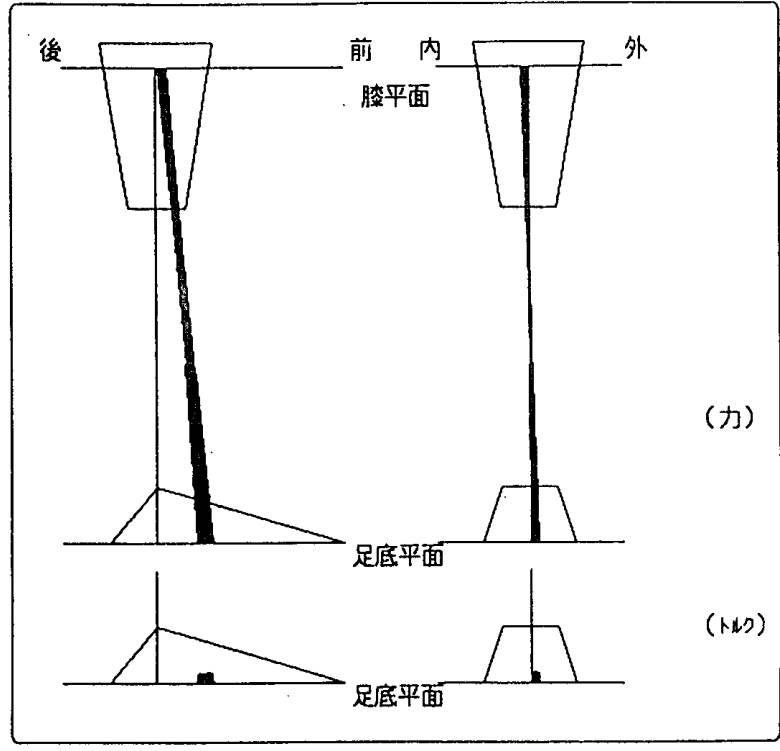

(a)哨的アライメント終了時

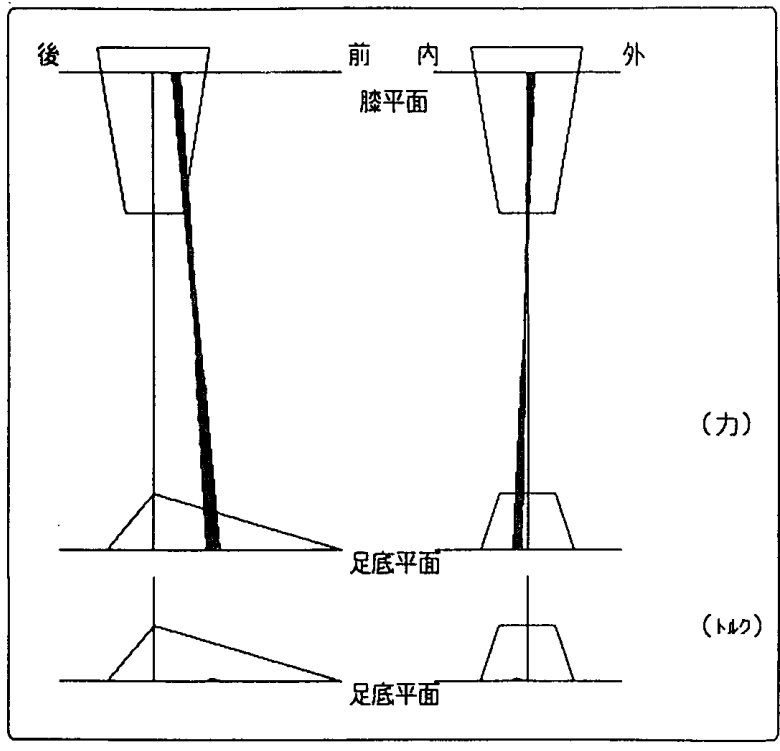

(b) 的アライメント终了時 (ソケット外転5度 足部外旋2度)

図 5.1 立位時の荷重線

義肢装具士：T.N., 被験者：T? O., (RBK 単軸足継手 PTBソケット).

別の義肢装具士 T.Y.による同一の被験者での アライメント調整過程の計測結果を，立位保持動作 について図 6.1 に, 平坦路歩行動作について図 6.2 に示す。立位保持動作では，(a)静的アライメント 調整終了段階と (b) 動的アライメント調整終了段階 で，荷重線の位置は殆ど変わらない。しかし，平坦 路歩行では，動的アライメント調整終了時には静的 アライメント調整終了時に較べてトルクが小さくな り，義足に無理な回旋力が作用しなくなっている様 子がわかる。

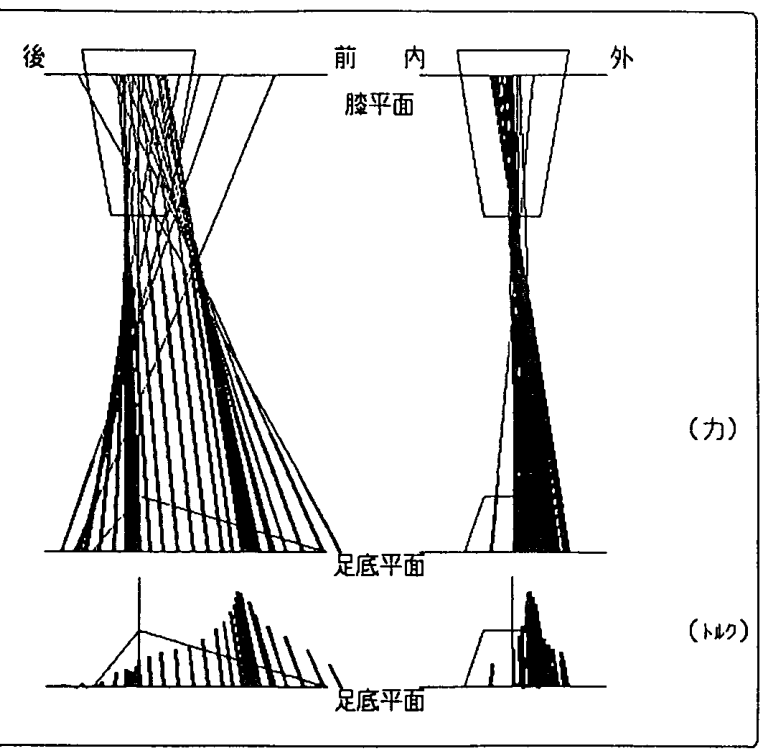

(a)静的アライメント終了時

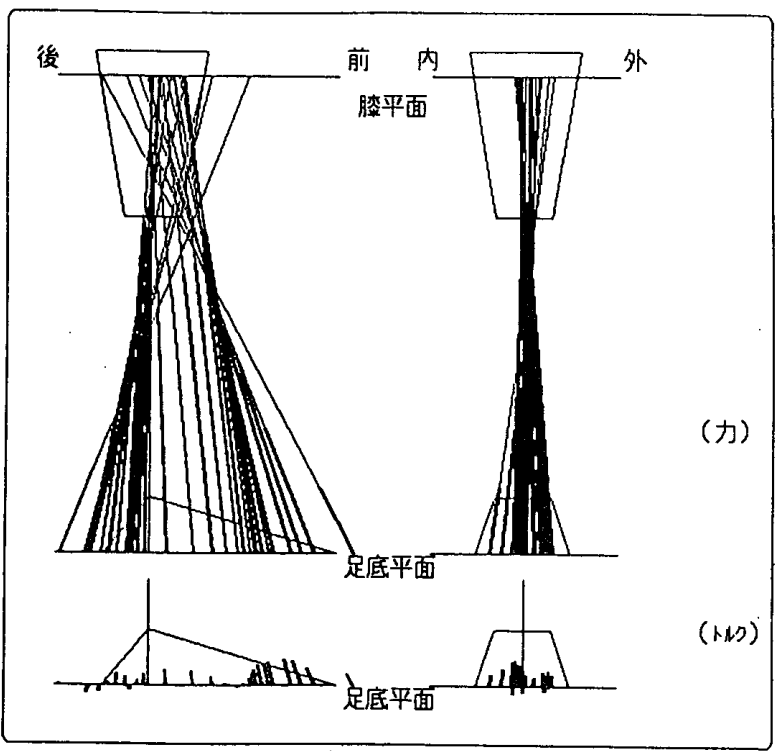

(b) 助的アライメンド終了時 (於外外転5度 足部外旋2度)

図 5.2 平坦路歩行時の荷重線の変化

義肢装具士：T.N., 被験者：T.O., (RBK 単軸足継手 PTBソケット).

\section{5. 膝継手の立脚制御機能の計測評価への 応用}

荷重ブレーキ機能を持つ滕継手の立脚制御機能を 計測評価するために，大腿義足の被験者に荷重ブレ 一キ膝継手を組み込んで，荷重ブレーキの作用の度 合いを(a)ブレーキ作用なし，（b)普通に効く状 態，（c) 良く効く状態の 3 段階に設定し，平坦路歩 行と坂道下り歩行 (最も荷重ブレーキ機能が要求さ れる)について実験的に調べた。 


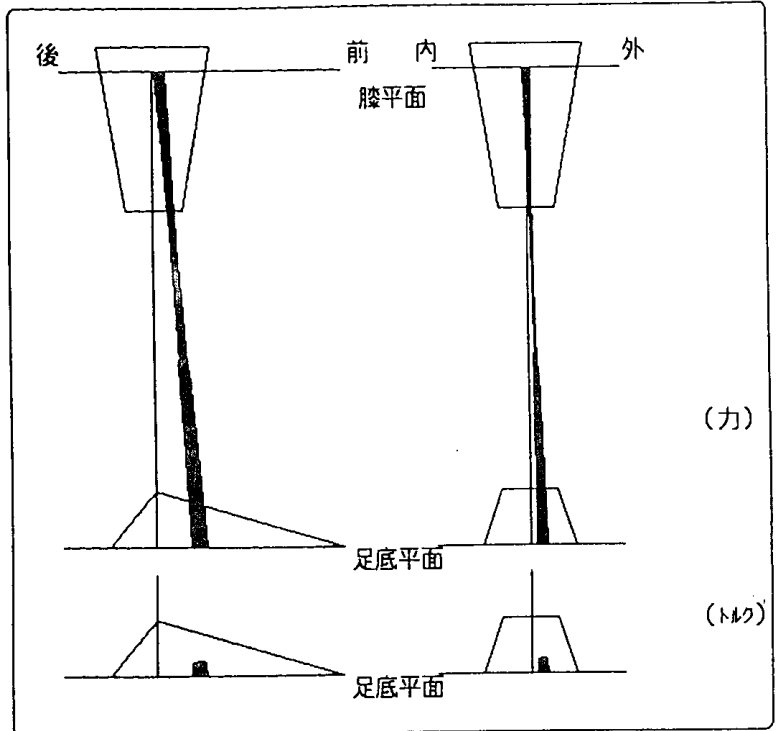

(a)解的アライメント終了時（足部底屈3度）

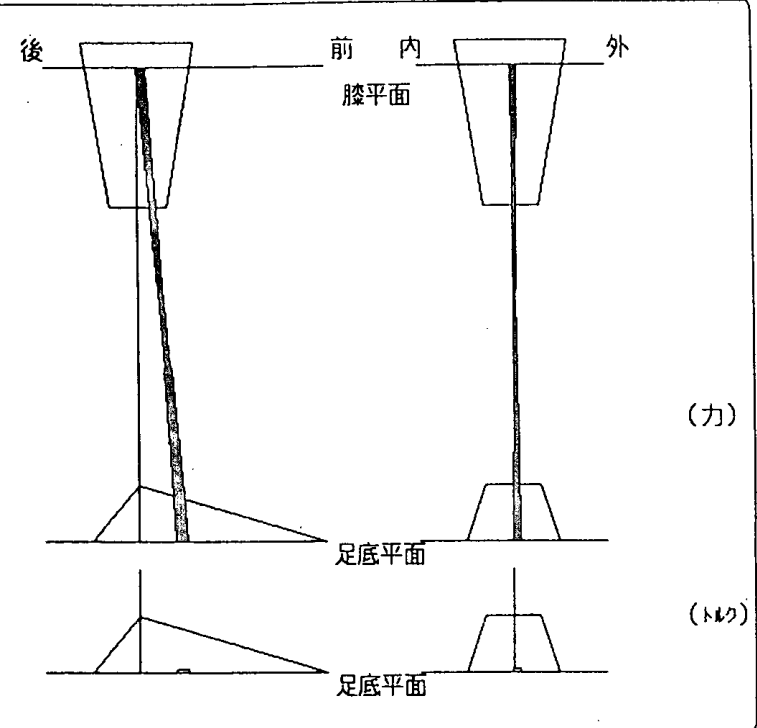

(b)叻的アライメント終了時(外外外忶2度 足部外旋2度)

图 6.1 立位時の荷重線

義肢装具士：T.Y., 被験者：T.O., (RBK 単軸足継手 PTBソケット).

\section{1 平坦路歩行時の立脚制御機能}

立脚期全体の荷重線の変化を図 7 に示す。立脚前 半の荷重線の変化については，荷重ブレーキの作用 の程度にかかわらず，ほとんど違いは見られない。 これは，被験者が通常，荷重ブレーキのない遊動膝 継手に慣れているためとも考えられる，逆に，立脚 期後半では（b)，（c）の場合に膝継手の後方を荷重 線が通過して，膝継手を屈曲させる曲げモーメント が大きく作用しており，これらの曲げモーメントに

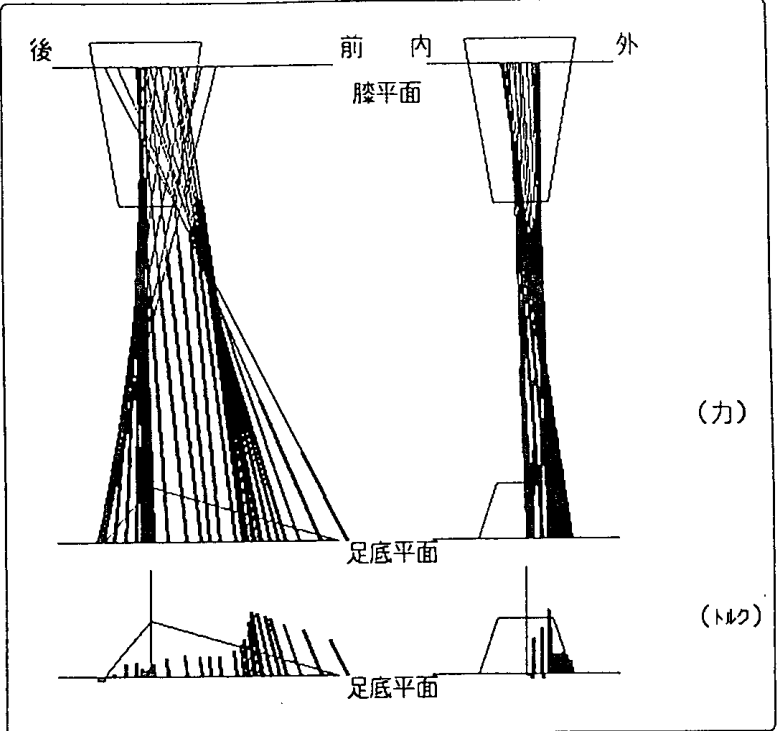

(a)觧的アライメント終了時（足部底屈3度）

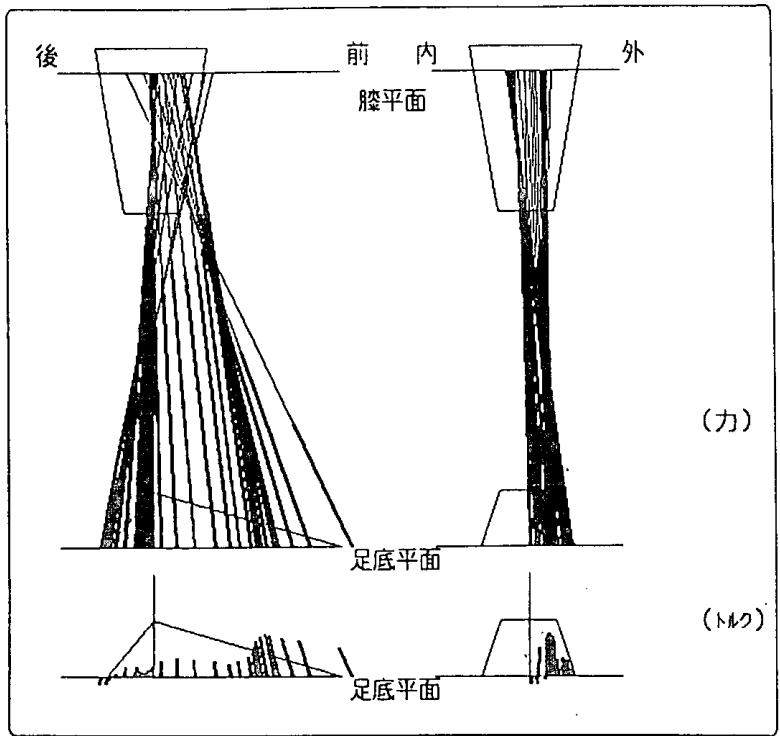

(b) 助的アライメント終了時 (リケケト外坛2度 足部外旋2度)

図 6.2 平坦路歩行時の荷重線の変化 義肢装具士：T.Y., 被験者：T.O., (RBK 単軸足継手 PTBソヶット).

耐えるブレーキ作用が膝継手に作用していることを 示している。荷重ブレーキを普通に効かせた状態 （b）では，荷重ブレーキを作用させない場合（a）に 較べて膝軸後方を通過する荷重線が少し後方寄りに なるだけであるが，荷重ブレーキが良く作用する状 態 (c)では殆ど固定膝継手に近い状態になり，遊脚 への移行を妨げていることを示している。

\section{2 坂道下り歩行時の立脚制御機能}

荷重ブレーキが最も重要になる坂道下り(傾斜 


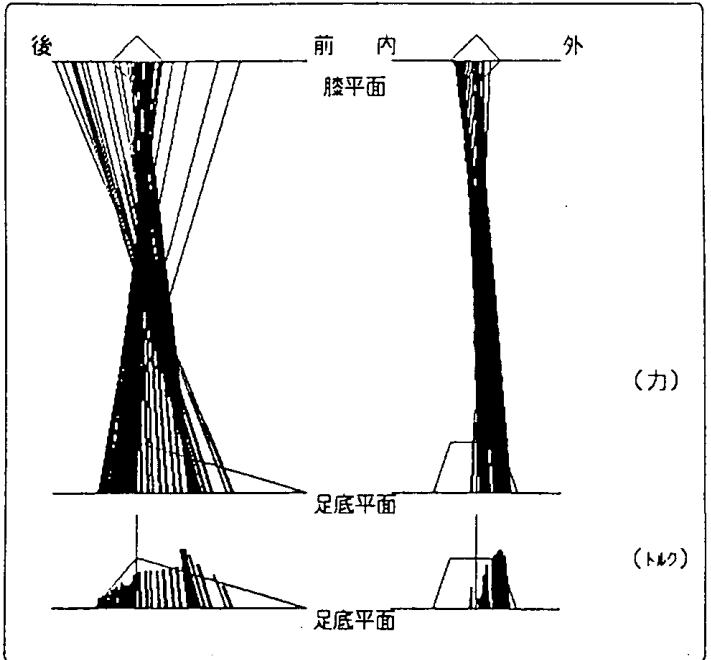

(a) 作動なし

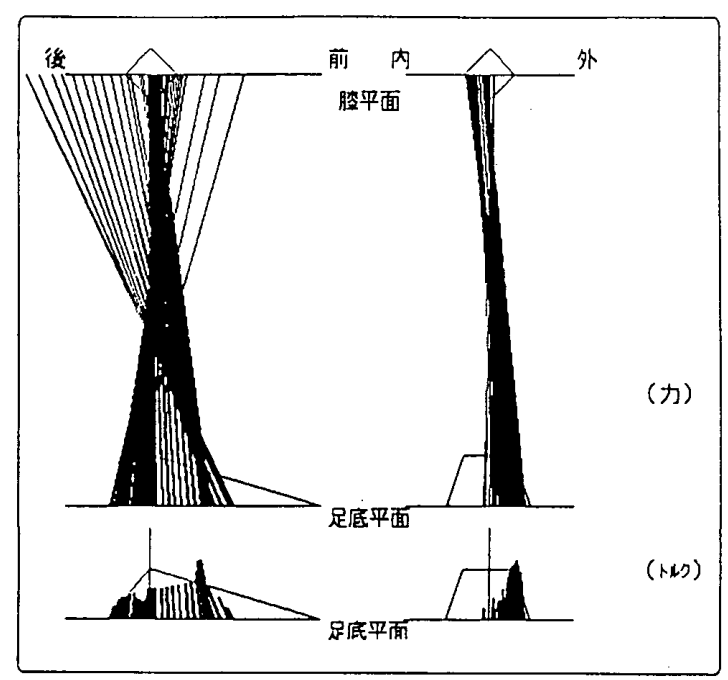

（b）作動（谱通）

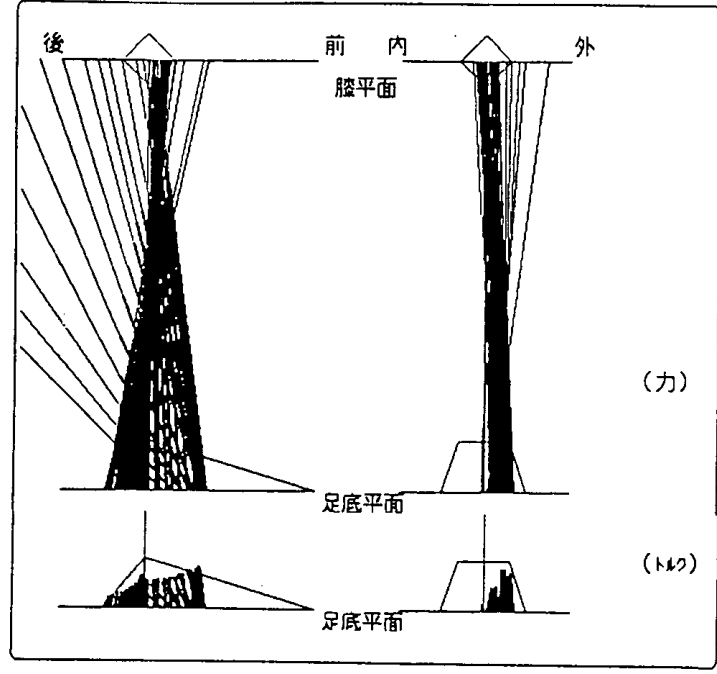

（c）作黝（ロックに近い状態）

図 7.1 平坦路歩行時の荷重ブレーキ機能の効き具合と荷 重線の関係

義肢装具士：T.Y., 被験者：T.K. (LAK 荷重ブレーキ膝 継手単軸足).

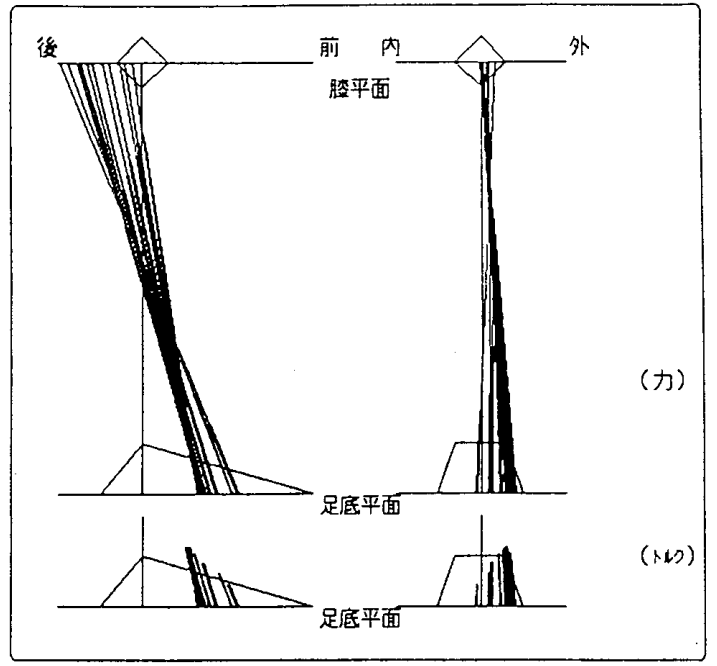

（a）作動なし

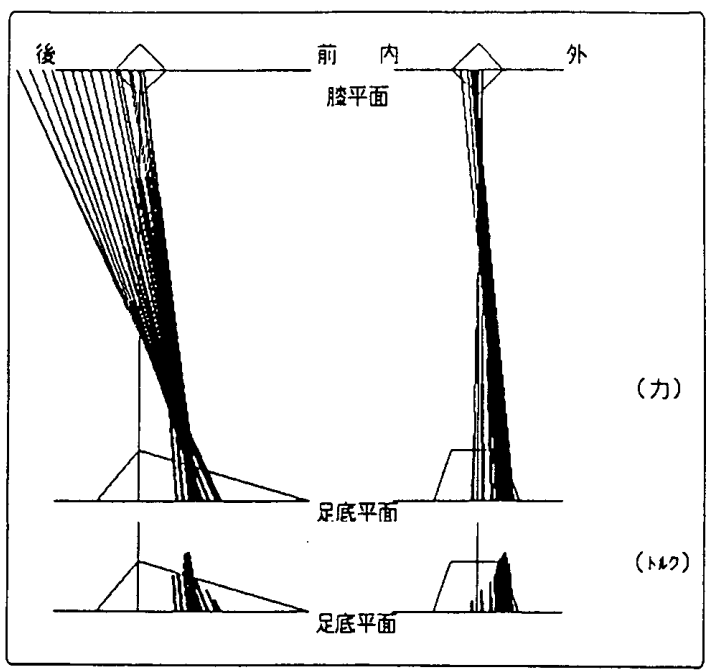

（b）作趿（䉕通）

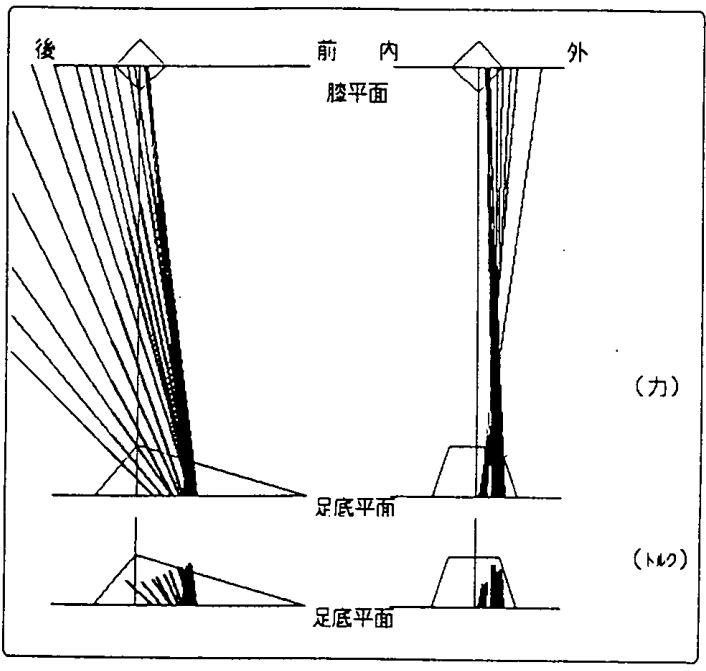

（c）作勳（ロックに近い状態）

図 7.2 平坦路歩行時の荷重ブレーキ機能の効き具合と立 脚期後半の荷重線との関係

義肢装具士：T.Y., 被験者：T.K. (RAK 荷重ブレーキ膝 継手単軸足). 


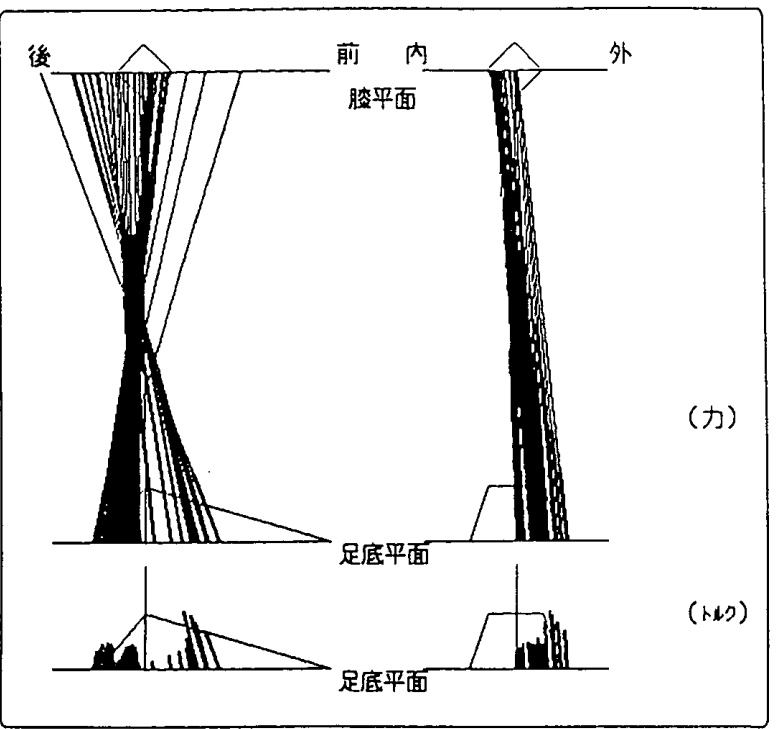

(a) 作野なし

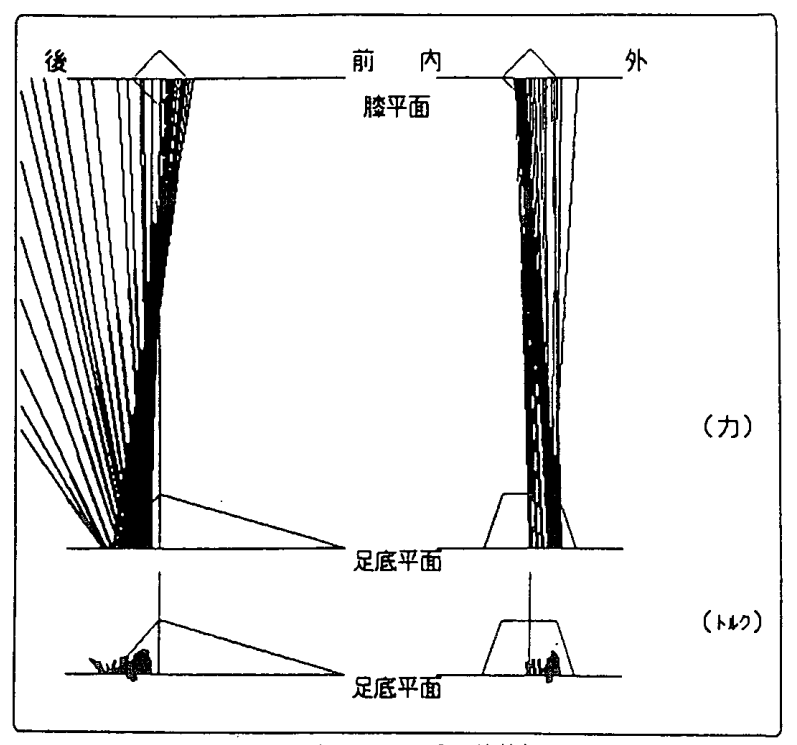

(b) 作功（ロックに近い状態）

図8.1 坂道下り（10 度）歩行時の荷重ブレーキ機能の効き 具合と荷重線の関係

義肢装具士：T.Y., 被験者：T.K. (RAK 荷重ブレーキ膝継 手単軸足).

10[度]）歩行で，（a )ブレーキ作用なし，（b）良く 効く状態，の場合の荷重線の変化を計測した結果を 図 8に示す。接踵時の荷重線は ( a )が ( b ) に較べ て膝軸前方寄りになっている。荷重ブレーキが作用 しないために，膝継手の前方寄りを荷重線が通るよ うに接踵して，アライメント上，膝継手に屈曲モー メントが作用しないようにしていると考えられる。 これに対して荷重ブレ一キを良く効かせた状態 (b) では，荷重ブレーキが作用するために，膝軸に近い ところを荷重線が通過すると考えられる。立脚期後

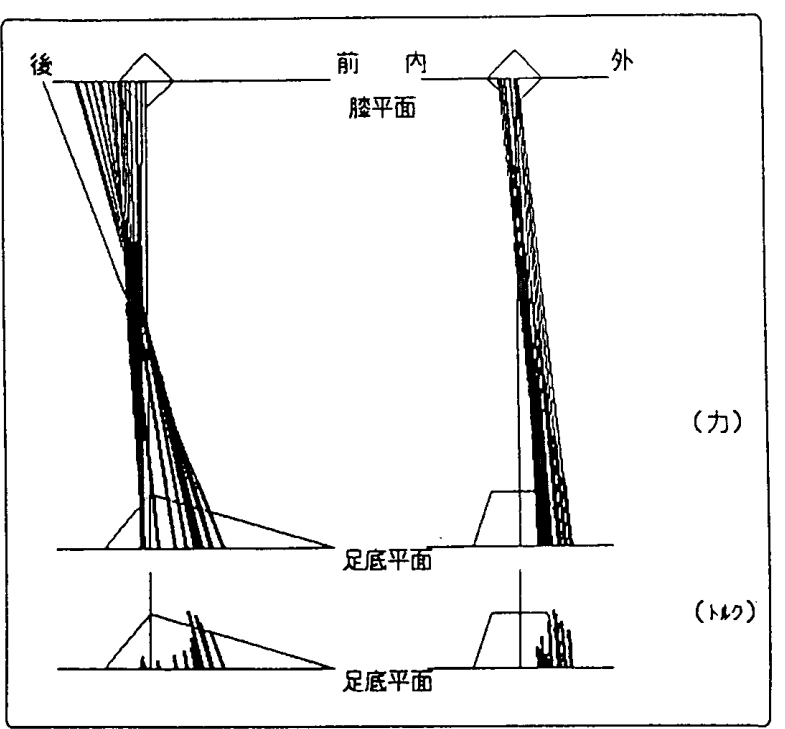

(a)作㢦なし

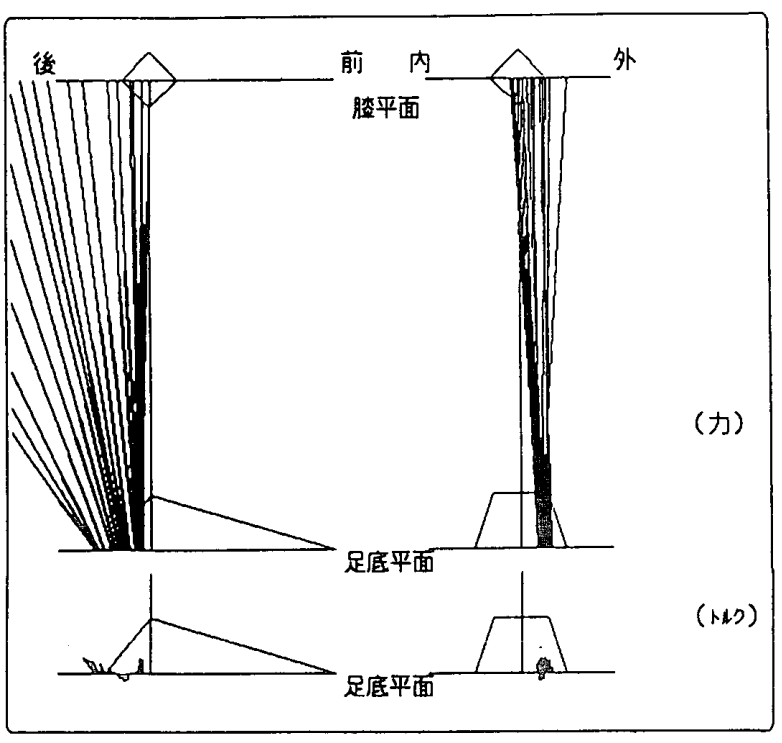

（b）作鸟（ロックに近い状孯）

图 8.2 坂道下り (10 度) 歩行時の荷重ブレーキ機能の効き 具合と立脚期後半の荷重線との関係

義肢装具士：T.Y., 被験者：T.K. (RAK 荷重ブレーキ膝継 手単軸足).

半では，（b）は（a）に較べて膝軸の後方まで荷重線 が作用して滕軸まわりに大きな屈曲モーメントが作 用しており，荷重ブレーキが実際によく作動してい ることを示している。

\section{6.おわりに}

下腿義足アライメントの調整手順を工学の立場か ら再構成して考察し，その過程から，義足に作用す る力学量を可視化することがアライメント調整過程 
を定量的に把握する上で役立つと推定した。これを リアルタイムで実現するシステムをパイロン・スタ ディ計測手法を応用して試作し，義肢装具士による 下腿義足のアライメント調整過程の各段階に抢ける 荷重線の変化の様子を立位保持動作と歩行動作につ いて，また，大腿義足の荷重ブレーキ膝継手の機能 について平坦路歩行と坂道下り歩行について計測し た. その結果，アライメント最適化に伴い，荷重線 まわりのトルクが隇少する傾向が共通して観察され るなど，系統的なパターンの変化が見られた。ま た，荷重ブレーキ機能の作用の様子を立脚期の荷重 線の方向と大きさから推定することができた。

これらのことから，本システムは，義足アライメ ント調整の過程において，従来，義肢装具士が重鍾 を用いて判断していた経験的な方式に替わる合理的 な解決法を工学サイドから提供できる方式であると いえる。

今後さらにデー夕を蓄積し，系統的な変化の傾向 を明確に捉えられるようにするとともに，システム
の操作性の向上や理解のしやすさなどを一層進め, 義足調整の現場で役立てられるように改良していく 予定である。

謝辞

計測実験に協力いただいた労災リ八工学センター研究員の 小山憲路，太田一重の両氏，および臨床面からの助言をいた だいた青山孝先生に感謝いたします。

\section{参考文 献}

1）森本正治,他：移動式義足歩行機能計測システム，バイ オメカニズム学会編, バイオメカニズム 8 , 東京大学出 版会, 251-263，(1986)。

2）森本正治,他：移動型義足歩行機能計測システムによる 各種歩行路における義足の足部・足継手部の機能評価, バイオメカニズム学会編, バイオメカニズム 10 , 東京 大学出版会, 185-193, (1990).

3）澤村誠志編：義肢学，192-203, 医歯楽出版，(1988).

4）森本正治,他：導電性ゴム方式 2 軸型フレキシブル関節 角度計の開発, バイオメカニズム学会編, バイオメカ二 ズム 12, 東京大学出版会, 223-230, (1994). 


\title{
DEVELOPMENT OF REAL-TIME LOAD LINE DISPLAY SYSTEM AND APPLICATION TO PROSTHETIC ALIGNMENT
}

\author{
Shoji MORIMOTO and Tamotsu YAMASHITA
}

\section{ROSAI Rehabilitation Engineering Center}

A general method to get the best alignment of trans-tibial (BK) prostheses was analysed on the basis of mechanics and it was concluded that useful information is supplied by a system which can display mechanical quantities (forces and moments) exerted on a trans-tibial prosthesis in real time.

From this viewpoint, a system containing a pylon load cell installed in the shank of the prosthesis to measure six quantity forces, flexible electro goniometers made of electroconductive rubber placed on the side of ankle and/or knee joint, and a portable data processing subsystem was developed. The whole system weighs less than $10 \mathrm{~kg}$, and is movable anywhere. From the output of the transducers, the load line on which the resultant force and moment work and are parallel to each other is calculated and displayed on the graphic plane of the micro computer in real time.

With this system, prosthetic alignments and prosthetic functions were measured and evaluated. The load lines in standing posture and in level walking were measured and compared with the process of aligning a trans-tibial prosthesis by some skilled prosthetists on the same amputee. After each stage of bench, static and dynamic alignment, load line shows a peculiar pattern of its own. The resultant moment (torque on the load line) tends to decrease from bench to static and from static to dynamic alignment.

The stance phase control function of a prosthetic knee joint was measured in a trans-femoral (AK) amputee for level walking and ramp descent. The amount of knee braking on stance phase was set in the three positions of free, normal and lock. With the knee braking mechanism working, load line comes to pass behind the knee axis in level walking. In ramp descent, more significant phenomena were observed compared than in level walking.

From the real-time display of the load line acting on the prosthesis, problems of static alignment, dynamic alignments and functions of joints will be made clear and the way to get better alignment and better function can be easily estimated. 